\title{
A Balance of Risks: The Protection of Human Rights in International Arms Trade Agreements
}

\author{
Borja Álvaro Álvarez Martínez ${ }^{1}$ \\ Independent Researcher \\ borjaalvaro20og@hotmail.com
}

\begin{abstract}
This article seeks to explore the possibilities and limitations that the introduction of human rights sensibilities within arms trade treaties has. It will compare and analyze the leading instruments in this field, namely the Arms Trade Treaty and the Council of Europe Common Position 2008/944/CFSP. It will be argued that these instruments, in spite of the issues common to both instruments, such as the employment of blurred terms, unclear guidelines, lackluster implementation, are however, the flexible frameworks that will allow for future improvements, and a growing relevance of human rights risk assessments within international arms trade.
\end{abstract}

\section{Keywords}

arms trade - human rights - public international law - due-diligence - trade agreements - human security - prevention

The interaction between arms trade and human rights is, in most scenarios, far from positive. In fact, international arms trade has been often considered the subject of a plethora of grievances, such as food deprivation, disease, disability, separation of families, loss of education, sexual abuse, torture, slavery and

1 Borja Álvaro Álvarez Martínez, MA, LLM, is alumnus of the University of Utrecht.

(C) BORJA ÁLVARO ÁLVAREZ MARTÍNEZ, 2019 | DOI:10.1163/18750230-02901008

This is an open access article distributed under the terms of the prevailing CC-BY-NC license at the time of publication. 
death by fuelling global armed conflict. ${ }^{2}$ The common ground of these harms is that they are all violations of protected human rights, and as such have come to be known as the "negative impact" of arms transfers on human rights. ${ }^{3}$ Furthermore, by diverting importing State's budgets into arms imports over other needs such as education, healthcare or other strategic sectors, ${ }^{4}$ arms trade also creates costs of opportunity. If we consider that in 2015 arms transfers amounted to 80 billion USD, the impact of these "costs of opportunity" cannot be underestimated. ${ }^{5}$ With this background, this article will examine what the relevant arms trade regulation can do to prevent these human rights violations, and how the need to protect human rights abroad interacts or conflicts with the drive to protect arms transfers.

Even if arms transfers fulfil legitimate security needs of importing States, ${ }^{6}$ due to the a priori pernicious influence that arms trade may pose to the enjoyment of human rights, clauses seeking to minimize those harms have been appearing slowly but steadily in the relevant international legal instruments that regulate this trade. For the purposes of this article, two legal instruments will be studied. First, the Council of the European Union Common Position 2008/944/CFSP is of relevance because it incorporates human rights concerns in a document that legally binds States whose combined arms exports amounts to more than the $26 \%$ of the global total. ${ }^{7}$

Moreover, it is relevant because it set the stage for its international counterpart, the Arms Trade Treaty (ATT), which itself was heavily sponsored by the European Union. ${ }^{8}$ This document will be the second focal point of this article. In short, the ATT shares similarly principled human rights clauses with regard to arms exports as those found in the Common Position, but aspires to be a truly universal treaty. In this article, it will be argued that these documents

2 Southall, D.P. "Empty Arms: The Effect of the Arms Trade on Mothers and Children." Bmj 325, no. 7378 (2002), p. 1459.

3 Human Rights Council, Impact of arms transfers on the enjoyment of human rights, A/ HRC/35/8 3 May 2017 Para. 6.

4 Human Rights Council, Impact of arms transfers on the enjoyment of human rights, A/ HRC/35/8 3 May 2017 Para. 8.

5 R. Stohl. "Understanding the Conventional Arms Trade." AIP Conference Proceedings 1898, no. 1, 2017, p.1.

6 Human Rights Council, Impact of arms transfers on the enjoyment of human rights, A/ HRC/35/8 3 May 2017 Para. 5 .

7 A. Fleurant et al., "Trends in International Arms Transfer", Stockholm International Peace Research Institute, 2017.

8 J.L. Erickson. "Market imperative meets normative power: Human rights and European arms transfer policy." European Journal of International Relations 19.2 (2013): 209-234. 
share a common framework that goes beyond the previous stringent notions of "complicity"9_, and impose human rights due-diligence obligations for arms transferring States, ${ }^{10}$ thus effectively creating new positive obligations for the States involved..$^{11}$ In summary, it will be discussed here how the current human rights assessment clauses in both the ATT and the Common position can be used to trigger "due-diligence" obligations of state parties, therefore creating an obligation to prevent human rights violations resulting from their arms trade practices.

It is this context, in which the conflicting worlds of arms trade agreements and international human rights law continuously challenge and compete with one another, ${ }^{12}$ that this article will explore precisely how human rights concerns interact with the current legal framework that regulates the arms trade. In order to gain an understanding of this interaction, a series of topics will be discussed. Namely, it will be explored how human rights concerns have crystallized within the ATT and the Common Position, and what differences and similarities vis-à-vis human rights protection are present in these documents. In essence, this article seeks to analyse how human rights law has entered the normative framework that regulates arms transfers, including not only enduser human rights considerations, but also an awareness of the current NorthSouth distinctions that lie at the basis of the current supply-side models ${ }^{13}$ for a truly nuanced analysis.

The core idea posited in the ATT—namely, the need for human right's protection within global arms trade agreements-is not entirely new, inasmuch as the ATT both draws from previous arms exports control initiatives, ${ }^{14}$ and

9 A. Boivin. "Complicity and beyond: International law and the transfer of small arms and light weapons." International review of the Red Cross 87.859, 2005, 467-496., p. 469.

10 Acheson, Ray. "Starting somewhere: The arms trade treaty, human rights and gender based violence." Hum. Rts. Defender 22, 2013, 17, p. 18.

11 A. Boivin, (n 9), p. 469.

12 N. Cooper, "What's the point of arms transfer controls?." Contemporary Security Policy 27.01, 2006, 118-137., p. 118.

13 A. Stavrianakis, Taking aim at the arms trade: NGOs, global civil society and the world military order. Zed Books Ltd., 2013. P. 30.

14 M. Bolton, and K.E. James. "Nascent Spirit of New York or Ghost of Arms Control Past?: The Normative Implications of the Arms Trade Treaty for Global Policymaking." Global Policy 5.4, 2014, 439-452. p. 448. 
is largely the result of EU normative entrepreneurship. ${ }^{15}$ In fact, the current status of human rights clauses in arms trade-related documents is closely knit to the leading role that the EU Code of Conduct on Arms Exports played globally. ${ }^{16}$ In short, the EU Code of Conduct required state parties to conduct a human rights assessment of the Country of Destination, ${ }^{17}$ an assessment that may then lead to the denial of arms export licenses or careful case-by-case vigilance and caution.

It thus created a two-tiered approach that prohibited arms exports in cases in which there was a clear risk of the arms being employed for internal repression, ${ }^{18}$ and had a more permissive approach in the cases in which potential human rights violations were not as egregious. Furthermore, and of quite some relevance, the EU Code also included a useful reporting system, ${ }^{19}$ even if it was an obscure one to the extent that denials and consultations within that framework were to be kept confidential by the relevant States $^{20}$ and the information was to be circulated only in regards to denied licenses. ${ }^{21}$

This structure is very much the cornerstone of the current Council Common Position 2008/944/CFSP, a binding document that regulates the arms trade in the EU, and has set the global standard. ${ }^{22}$ The Common Position sought to correct some of the issues that plagued the previous Code of Conduct, namely its non-binding nature and the inter-State undercut practices that resulted from States accepting transfers denied by other parties. ${ }^{23}$ As a result of these challenges, the Common Position must be understood as an attempt to balance the commercial needs of the European defense sectors and the need to avoid

15 Erickson, J.L. (2013) (n 8).

16 A. Bailes. "The EU and a 'Better World': What Role for the European Security and Defence Policy?." International Affairs, 2008, 115-130., p. 121.

17 Council of the European Union, 'European Union Code of Conduct on Arms Exports', document 8675/2/98 Rev 2, Brussels, 5 June 1998, Criterion 2, para. 4.

18 Council of the European Union, 'European Union Code of Conduct on Arms Exports', document 8675/2/98 Rev 2, Brussels, 5 June 1998, Criterion 2, section b).

19 N. Marsh, "Two sides of the same coin? The legal and illegal trade in small arms." The Brown Journal of World Affairs, 9.1, 2002, 217-228, p. 220.

20 Council of the European Union, 'European Union Code of Conduct on Arms Exports', document 8675/2/98 Rev 2, Brussels, 5 June 1998, Operative Provisions, para. 4.

21 Council of the European Union, 'European Union Code of Conduct on Arms Exports', document 8675/2/98 Rev 2, Brussels, 5 June 1998, Operative Provisions, para. 3.

22 A. Vranckx, F. Slijper, and R. Isbister. Lessons from MENA: appraising EU transfers of military and security equipment to the Middle East and North Africa: a contribution to the review of the EU common position. Academia Press, 2011., p. 3.

23 B. Gruselle and P. Le Meur. "Technology transfers and the Arms Trade Treaty: issues and perspectives." Recherché \& Documents 2, 2012, 5-8., p. 16. 
extremely pernicious arms transfers. ${ }^{24}$ With regard to the latter interest, the Common Position can be understood as an effort to make legally binding the criteria already stated in the Code of Conduct. ${ }^{25}$

Indeed, just as in the Code, the Common Positions sets a two-tiered system of human rights protection: any goods at risk of being used for internal repression through breaches of human rights must be denied their relevant transfer licenses. ${ }^{26}$ However, if the violations of human rights do not reach the threshold of "internal repression" the Common Position does only require "special caution and vigilance". ${ }^{27}$ While this does indeed make binding the system devised in the previous Code, it is problematic from a Human Rights perspective: What amounts to "internal repression" and "clear risk", and thus mandates arms transfer prohibitions? What is a "serious violation of human rights" and requires only special caution? Without explicit and stark definitions of these matters, it is unclear under what circumstances a certain arms transfer ought to be rejected, and therefore it blurs the practical application of the Common Position.

Even if attempts have been made to clarify the scope of these provisions, little guidance is provided beyond remittance to whether the UN or the EU have qualified a particular violation as "serious". ${ }^{28}$ As such, there is a need for case-by-case analysis, but there is still next to no substantive guidance provided, while far too much depends on State's interpretation. The same issues ring true with regard to what exactly is meant by "internal repression", which is only linked to breaches of human rights via torture, cruel, inhumane and degrading treatment and arbitrary detentions. ${ }^{29}$ Furthermore, the inclusion of a "clear risk" clause makes matters far from clear, since from EU regulations it can only be asserted that an evaluation of 'clear risk' requires a case-by-case

24 A. Vranckx, F. Slijper, and R. Isbister. (n 22), 2011, p. 10.

25 S.T. Hansen and N. Marsh. "Normative power and organized hypocrisy: European Union member states' arms export to Libya." European Security 24.2, 2015, 264-286., p. 269.

26 Council of the European Union, 2008. Council common position 2008/944/CFSP of 8 December 2008 defining common rules governing control of exports of military technology and equipment. Brussels: Council of the European Union. Art. 2.2.

27 Council of the European Union, 2008. (n 26).

28 Council of the European Union, User's Guide to Council Common Position 2008/944/ CFSP defining common rules governing the control of exports of military technology and equipment, 2009. P. 40.

29 See Council of the European Union, $2008\left(\mathrm{n}_{32}\right)$ and Council of the European Union, 2009 (n 34), p.41. 
analysis, and that at any rate "clear risk" is a lower threshold than that of absolute certainty. ${ }^{30}$

\section{Universal Reach: The ATT}

The Aтт can be considered as an effort towards the understanding that arms exporting countries also have a stake in preventing human rights violations. ${ }^{31}$ In some respects, it is the universal counterpart of the Common Position, and thus it will analyzed in some detail in this section. It does indeed represent an instrument with significant potential for the promotion of human rights by increasing international accountability and responsibility in the arms trade. ${ }^{32}$ It is necessary to make clear first and foremost that the ATT only prohibits exporting arms to countries under embargo, and does not prohibit by default exporting weapons to States that breach their human right obligations. ${ }^{33}$ Indeed, rather remarkably, human rights language is absent in the articles of the ATT that bar arms trade. This is surprising, inasmuch as one of the instruments that clearly inspired the ATT, the OSCE Principles, does include this kind of language. ${ }^{34}$ Instead, human rights considerations are dealt with by means of the art. 7 second regime, via a newly established mandatory human rights risk assessment. ${ }^{35}$ If after conducting this mandatory risk assessment the exporting States determines that their arms transfers may be used to commit or facilitate serious violations of international humans right law, they shall then consider whether they can introduce measures to mitigate those risks. ${ }^{36}$ Only after the consideration of these measures, if an "overriding risk" is still deemed to exist, are the States expected not to authorize their arms exports. ${ }^{37}$

\footnotetext{
30 Council of the European Union, 2009 (n 34).

31 E. Kytömäki, Elli. The Arms Trade Treaty and Human Security: Cross-Cutting Benefits of Accession and Implementation. Chatham House, 2015, P.2.

32 E. Kytömäki, 2015. Supra note p.22.

33 M. Bromley, N. Cooper, and P. Holtom. "The UN Arms Trade Treaty: arms export controls, the human security agenda and the lessons of history." International Affairs 88.5, 2012, 1029-1048, p. 1041.

34 P. Holtom, "The OSCE and the Arms Trade Treaty: Complementarity and Lessons Learned." osCE Yearbook 2015, 2016, (pp. 327-342), p. 334.

35 Arms Trade Treaty (Adopted 2 April 2013, entered into force 24 December 2014) United Nations, Arts 7.1 and 7.1 (ii).

$36 \quad$ Supra note Art. 7.2.

37

Ibid supra note. Art. 7·3.
} 
This state of affairs has been met with twofold criticism: first, the notion of "overriding risk" seems to give far too much leeway for treaty interpretation, ${ }^{38}$ and second, the introduction of possible mitigation measures as part of the human rights risk assessment frameworks is seen as allowing for the creation of normative loopholes vis-à-vis the protection of human security considerations. ${ }^{39}$ But in spite of these criticisms, the ATT does reflect several of the concerns of many States with regard to the arms trade. ${ }^{40}$ For example, the ATT provides a twofold system for arms trade reporting based around an implementation report and a transfer reporting system, ${ }^{41}$ designed to increase transparency and efficiency of arms transfer control initiatives. ${ }^{42}$ This system provides for the initial report to be submitted within one year of the Treaty entering into force, including, inter alia, the relevant domestic laws and regulations, controls and administrative measures pertaining arms trade, and how they comply with the Treaty. ${ }^{43}$ In addition, the annual report addresses the export licenses assessed in the preceding year. ${ }^{44}$

Controversially, however, States may exclude from these reports whatever information they may consider either "commercially sensitive" or relevant for "national security", 45 which potentially undermines the reporting procedure as a whole. In this respect, it can be said the ATT falls short of both its EU and OSCE counterparts. ${ }^{46}$ In short, the ATT does not opt for prohibiting arms exports when they present a risk vis-à-vis human rights violations, but rather it sets a regime which mandates first the assessment of said risks on a caseby-base basis. If a State were to ascertain the existence of such a risk, then it ought to develop mitigating measures, and only after these measures have been considered, and if these risks have been deemed to be "overriding", shall they legally deny the authorization for a given arm transfer.

\footnotetext{
$38 \quad$ E. Kytömäki, 2015, (n 31), p. 15.

39 M. Bromley, N. Cooper, and P. Holtom, 2012, (n 32) p. 1042.

$40 \quad$ Ibid supra nota, p. 1042.

41 B. Coetzee. Arms Trade Treaty: Ratification and Implementation Guide for African States. Institute for Security Studies, 2014, p. 69.

42 United Nations Office for Disarmament Affairs (UNODA), A succinct, practical guide to all relevant ATT implementation measures. (ATT IMPLEMENTATION TOOLKIT) Module 3: Reporting Requirements, p. 2.

43 UNODA, Ibid supra note, p. 3.

44 B. Coetzee, 2014, (n 41).

45 UNODA, (n 42) p. 5 .

46 L. Simonet. "The Arms Trade Treaty and the osce." Security and Human Rights 25.4, 2014, 440-453.
} 
Having discussed how human rights concerns appear in the most relevant current arms trade instruments and the obligations they create, we will now turn to compare each of the two aforementioned systems from a functionalist perspective. This shall enrich the study of systems that purport prima facie to regulate similar themes. ${ }^{47}$ As it has been discussed, both the ATT and the Common Position establish the need to assess human rights risks, and do so quite straightforwardly: “[h]aving assessed the recipient country's attitude towards relevant principles established by international human rights instruments, Member States shall...,, 48 and that "...each exporting State Party, prior to authorization of the export of conventional arms... ...shall assess the potential that the conventional arms or items could be used to commit or facilitate a serious violation of international human rights law...". 49

Although these statements signify a common ground by both requiring mandatory assessments of the human rights impacts of a certain arms transfers, it can be already seen that the grounds for such assessments are different. For one, the Common Position arguably seeks to evaluate the overarching human rights situation in a certain importing State, ${ }^{50}$ whereas from the wording of the ATT the assessment seems to be focused on a more intricate analysis involving the kinds of weaponry to be transferred and their usage vis-à-vis concrete human rights obligations. ${ }^{51}$ However, despite the language of the ATT itself, its associated soft law documents, such as the ATT Toolkit, return to the traditional approach that places the risk factors not in the arms transferred, but in the conditions of the receiving State. As such, risk assessment criteria for the ATT return to the Common Position formula, which evaluates policy, treaty implementation and accountability mechanisms. ${ }^{52}$ It is argued that the need for nuanced analysis of arms transfers is fundamental, because

47 P.G. Monateri, ed. Methods of comparative law. Edward Elgar Publishing, 2012, p. 62.

48 Council of the European Union, 2008. (n 26).

49 that “...each exporting State Party, prior to authorization of the export of conventional arms... ...shall assess the potential that the conventional arms or items could be used to commit or facilitate a serious violation of international human rights law...".

$50 \quad$ Council of the European Union, 2009 (n 28).

$5^{1}$ The wording "Asses the potential that the conventional arms or ítems" suggests an equipment-based human rights risk assessment, however, only two of the fourteen risk indicators outlined in the ATT Implementation Toolkit pertain an analysis of the risks inherent to the weapons systems, whereas the remaining 12 pertain the general human rights background of the importing State. UNODA, (n 42), p. 13. 
a weapon's ability to violate human rights greatly varies depending on the particular weapon system exported. ${ }^{53}$

In short, the wording of both documents suggest a priori differences in the approach chosen to evaluate the human risks associated to a given arms transfer, but the associated grey literature quickly dispels this idea. The criterions and approaches employed in both instruments to benchmark risks, such as adherence to human rights treaties and domestic law-making and policy are identical. ${ }^{54}$ Indeed, this similarity is so complete that it perhaps serves as evidence of the degree to which European normative entrepreneurship has influenced international arms trade regulations, such as those found within the ATт. ${ }^{55}$

\section{5}

\section{Defining Acceptable Risk Thresholds}

Both the ATT and the Common Position seek to assess and evaluate the human rights risks associated with a certain arms transfer so as to control transfers that reach a certain degree of potential harm. This section seeks to clarify the thresholds established in each of the instruments to that end. For starters, the ATT sets two different levels: potential human rights risks are determined with a "could be used" 56 clause whereas transfers shall be denied when that potential risk is deemed "overriding". ${ }^{57}$ On the other hand, the Common Position provides similar thresholds employing the wording "might be used" and "clear risk"58 to describe the thresholds between transfers whose human rights risks are acceptable and those who are not.

Both approaches suffer from the same problems insofar as they require extensive interpretation due to their ambiguity. In fact, this ambiguity has been duly considered as a sign of State's resistance against these arms trade regulations. ${ }^{59}$ In the context of the Common Position, this was shown in the harsh negotiating process with both France and the UK, whereas at the ATT level,

53 J.R. AI, and S.L. Willardson. "Human Rights and Democratic Arms Transfers: Rhetoric Versus Reality with Different Types of Major Weapon Systems." International Studies Quarterly 62.2, 2018, 453-464, p. 457 .

54 Council of the European Union, 2009 ( $\mathrm{n} 28$ ).

55 J.L. Erickson, 2013. (n 8).

56 ATT, art. 7.1. (b).

57 ATT, art. 7.1. (b).

58 Council of the European Union, 2008. (n 28), Art. 2.5.

59 S.T. Hansen, "Taking ambiguity seriously: Explaining the indeterminacy of the European Union conventional arms export control regime." European Journal of International Relations 22.1, 2016, 192-216., p. 210. 
the US played a fundamental role in creating possible "national security" loopholes, while the Russian Federation opposed the Treaty altogether (and is currently not even a signatory). This ambiguity further undermines the strength of both documents because very little additional interpretative guidance is provided to understand these thresholds. For example, the ATT's "could be used" formula seems to suggest a lower level of certainty required than the one needed to trigger Art. 7.1 (a), which includes the wording "would". As a result, the ATT does not impose neither clear nor conclusive risk assessment thresholds. Another example of this trend is the notion of "overriding risk" put forth in the ATT, which is not explained whatsoever in any associated grey or technical literature, and thus needs to be understood as higher than just a substantial risk. ${ }^{60}$ In this regard, it has been suggested that the term "overriding risk" ought not to be understood as a substantive threshold, but rather as an obligation to weigh the human rights risk of a certain arms transfers against its theoretical positive outcomes, such as its possible contribution to peace and security ${ }^{61}$

For its part, the Common Position faces a similar scenario. It also employs two different risk assessment thresholds, "might be used" and "clear risks". The interpretation of these concepts seems to be intertwined, as it is suggested that they create a lower risk threshold than the certainty of a clear risk that the equipment will be used for human rights violations. ${ }^{62}$ Again, the only interpretative guidance provided is that the risks that the arms transferred will be used for human rights violations needs to be lower than that of absolute certainty. However, it has been argued that the use of the wording "clear" requires not mere human rights risks, but rather a more nuanced threshold, thus envisaging the Common Position's more restrictive approach in terms of required risk to deny a transfer. ${ }^{63}$ However, the grey literature associated to the Common Position suggests otherwise. Indeed, it seems that the term "clear" does not qualify the risk itself, but rather refers to the quality of the information on which the analysis is made, requiring detailed and up-to-date information. ${ }^{64}$ Essentially, instead of positing the need of a self-evident or clear risk, the Common Position requires the use of clear indicators to measure the degree of the human rights risks involved in a certain arms transfer. However, it fails to elaborate on what those clear risks indicators ought to be. This is important because it

$60 \quad$ S.T. Hansen, 2016. Ibid. supra note.

61 UNODA, (n 42), p. 16.

62 Council of the European Union, 2009, (n 28).

63 Z. Yihdego. "The EU's Role in Restraining the Unrestrained Trade in Conventional Weapons." German Law Journal 10.3, 2009, 281-303., p. 286.

64 Council of the European Union, 2009. (n 28), p. 42. 
leads not to a more stringent understanding of the requirements posited by the Common Position, but rather to the need of clear sources and data to conduct these risk assessments, which is a welcome addition. This would be in line with the credited commitment from the EU to the promotion of human rights abroad, ${ }^{65}$ particularly through trade. But this does not mean that this substantive effort does not contain serious questions regarding the consistency of its application, ${ }^{66}$ particularly if it places so much emphasis on such unclear clauses. Again, this lack of clear boundaries has been attributed to the heterogeneous negotiating position and State resistance linked to material interests within the EU. 67

What needs to be highlighted is that, unfortunately, neither the ATT nor the Common Position do have clear risk boundaries: by just looking at the legal instruments or their soft law counterparts it is not possible to make an assessment of whether a risk is clear enough, overriding enough or directly linked to a particular arms trade so as to preclude it automatically. The interpretative criterions provided by the legal frameworks of reference in order to do so are either blurred or non-existent. This shared commonality may undermine the efficiency and efficacy of both instruments in their purported protection of human rights abroad. This is so because it leaves much interpretative leeway for States, bringing to the forefront the underlying struggle to accommodate the tension between conflicting interests: arms trade versus other human security considerations. In this balance, it is perceived as necessary to sustain arms industries, while trying to avoid exporting to countries with poor human rights records with increasing arms demand. ${ }^{68}$

\section{$6 \quad$ Discussing the Obligations Entailed}

Since, as has just been discussed, both the Common Position and the ATT include binding obligations to assess risk against certain thresholds (regardless of how blurred they may be), it is necessary to analyze now the possible outcomes of those assessments. In particular, the duties of the States after they have ascertained the levels of human rights risks of a given arms transfers will now be detailed.

\footnotetext{
65 M. Bromley. The Review of the EU Common Position on Arms Exports: Prospects for Strengthened Control. EU Non-Proliferation Consortium, 2012, p.5.

66 Z. Yihdego, 2009. (n 62) p. 294.

67 S.T. Hansen, 2016. (n 59), p. 207.

68 S.T. Hansen, 2016. Ibid. supra note.
} 
Beginning with the Common Position (arguably the more straightforward of the two documents), a twofold pattern of action can be ascertained from its wording. If a given arms export meets the aforementioned clear risk threshold of being used for internal repression, that export license simply ought to be denied. ${ }^{69}$ It is much less straightforward however if the assessments ascertain that there are indeed human rights risks, but those violations are not be so grave or clear-cut. In this scenario, States are only bound to exercise "special caution and vigilance" in the issuance of arms exports authorizations, provided that serious violations of human rights have previously taken place in the importing States. ${ }^{70}$ It is understood that these denials can be issued at any point of an arms transfer negotiation, ${ }^{71}$ and require a formal governmental notification in writing, which shall include as a minimum the country of destination, a full description of the related goods, their quantity and their technical specifications if needed, the buyer and the proposed end user. ${ }^{72}$

Whereas the denials themselves are perceived as a tool for homogenization and development of export control policies within the EU, the outcome in the cases in which the clear risk threshold are not met is far less developed. As a matter of fact, while "special caution and vigilance" is prescribed for the issuance of licenses, neither the Position nor the User's guide provide any guidance whatsoever on the practices or controls that may amount to such caution and vigilance. This heightened threshold of vigilance is mandated in the cases in which the recipient countries have been engaged in serious violations of human rights. These terms are, far from self-evident, and accompanied by very little, or even contradictory, guidance by which to assess when a human right violation may be qualified as such. The efficient application of the "special caution and vigilance" would require taking into account the nature of the obligations engaged, the scale and magnitude of the violations, the status of the victims and the impact of the violations, so as to determine whether a violation of human rights is "serious" and shall include economic and social rights. ${ }^{73}$

In short, if a given arms export has a clear risk of being used for, inter alia, internal repression, the transfer shall clearly be denied. However, what States are bound to do in the cases in which it is ascertained that there is a human rights risk associated to an arms transfer, but not so grave nor direct, is far less

\footnotetext{
69 Council of the European Union, 2008. (n 31), art. 2(2) a.

70 Council of the European Union, 2008. (n 31), art. 2(2) a.

71 Council of the European Union, 2008. (n 31), art. 4(2).

72 Council of the European Union, 2009. (n 33), pp. 6-7.

73 T. Karimova. What amounts to a serious violation of international human rights law'? Geneva Academy of International Humanitarian Law and Human Rights (Geneva Academy), 2014.
} 
clear cut. It is necessary to clarify and develop this regime of enhanced protection if it purports to offer a credible and consistent application.

On its part, the AтT provides for different potential outcomes. Once the human rights risks of a certain arms exports have been assessed, even if found to exist in relation to the commission or facilitation of a future serious violation of human rights, there is no prima facie obligation to deny such export as the Common Position mandates through its Art. 2.2 (b). Instead, in the event of risk being found, the ATT binds state parties to consider whether mitigating measures can be put into place between them and the importing States. ${ }^{74}$ As it has been criticized, the inclusion of mitigation measures has been regarded as either a loophole allowing the evasion of human rights considerations and to assure the US that their national security interests would not be interfered with, or as means to induce confidence-building measures between exporting and importing States. ${ }^{75}$

The mitigating measures can generally be either confidence-building measures or agreed programmes. ${ }^{76}$ The former include inter alia enhancement of transparency in military matters, disclosure of the importing state's human rights records and declaration of the intent and purpose of use of the transferred items, ${ }^{77}$ whereas the latter require inter-state cooperation, such as postdelivery monitoring, joint efforts to increase systems control capabilities, and diversion prevention, among others. ${ }^{78}$ It is only when these measures are introduced, and if there are still human rights risk that override other security considerations, that a given arms transfer shall be denied.

In short, this shows how the ATT and the Common Position posit different models when it comes to addressing what ought to be done when human rights risks are found to be associated with a certain arms transfer. For its part, the Common Position mandates a denial of such transfers in which there is a clear risk of the equipment used for internal repression, or a broad scrutiny when the transfer is done towards States with a poor human rights records. The ATT, however, provides a system of balances: if risks are found in the assessment of a given arms transfers, a chance is given to mitigate and reduce them via the introduction of measures. Only if these measures are deemed insufficient, and in cases in which human rights risks override other considerations such as national security, shall the transfers be denied.

\footnotetext{
$74 \quad$ ATT, art. 7.2.

75 M. Bromley, N. Cooper, and P. Holtom, 2012 (n 38), p. 1042.

76 B. Coetzee, 2014 (n 41), p. 35.

77 UNODA, (n 42).

78 UNODA, (n 42).
} 
What may not be apparent from the previous sections is that both the Common Position and the ATT impose upon State Parties the obligation to assess risk before they authorize any export license, and then, given "clear" or "overriding" risks of human rights violations associated to these transfers, it binds them to deny these exports. This implies a shift of paradigm. Traditionally, States would only be legally responsible for their arms transfers if they were fully aware of their future use to violate human rights abroad, thus being complicit in international wrongful conduct. ${ }^{79}$ In that scenario, the relevant threshold of international legal responsibility is that of "complicity", only triggered in the event of a State acting with full knowledge. ${ }^{80}$ By contrast, what lies at the heart of the human rights provisions in the Common Position and the ATT is the prevention of human rights violations related to arms transfers. Indeed, both instruments opt for risk-management paradigms, with risk assessment being intrinsically intertwined to the human rights discourse on both of them..$^{81}$ Therefore, a new form of State responsibility is emerging from these regulations: that of due-diligence. ${ }^{82}$ Human rights due-diligence does not require the degree of knowledge posited for State complicity, and indeed is generally considered as the responsibility that arises from States failing to prevent and investigate human rights violations. ${ }^{83}$ It has gained increased

79 International Law Comission (2001) Draft articles on Responsibility of States for Internationally Wrongful Acts, with commentaries, Yearbook of the International Law Commission, Part II, p. 67.

8o International Law Commission, Draft Articles on Responsibility of States for Internationally Wrongful Acts, November 2001, Supplement No. 10 (A/56/10), Art. 16, and Case concerning application of the convention on the prevention and punishment of the crime of Genocide (Bosnia and Herzegovina v. Servia and Montenegro), Judgment, I.C.J. Reports 2007, p. 43, para. 423 .

81 Article 7 of the ATT includes notions of risk assessment in regards of the commission or facilitation of serious violations of human rights law, risk mitigation measures, and provides for denial of transfers when overriding risks of such violations are found. Similarly, the Common Position includes denials of exports when clear risks of violations of certain human rights are expected, and to exercise caution and vigilance in cases where the receiving countries have mixed human rights records.

82 J. Sherman and A. Lehr. "Human rights due diligence: Is it too risky." Corporate Social Responsibility Initiative Working Paper 55, 2010, pp. 6-7.

83 Human Rights Council, Impact of arms transfers on the enjoyment of human rights, A/HRC/35/8 3 May 2017 Paras. 19-20. 
traction within the field of human rights, ${ }^{84}$ and applies comprehensively to arms transfers: while the violations of human rights are committed by third parties, and therefore cannot be attributed directly to the exporting State, the responsibility is triggered regardless because said State failed to prevent a certain violation, ${ }^{85}$ which he had a stake in preventing via the mechanisms present in both the Common Position and the ATT.

In summary, it is argued that the ATT and the Common Position create a new threshold of State responsibility in regards of human rights and arms exports. To the extent that these instruments create obligations to assess risk and prevent violations, the threshold of certain knowledge needed for the assistance in the commission of an international wrongful act is no longer the framework of reference. Instead, it is whether they knew or ought to have known the existence of a real risk of human rights violations. ${ }^{86}$ The assessment of both documents shows how States are bound to operate within these margins of error: to the extent that complex and protracted consultations are required prior to any export, ${ }^{87}$ any State should by default either know or have known the humans rights risks associated to a particular arms transfer. The ATT even goes as far as stating that it is necessary to apply a human rights due diligence standard to arms transfers through effective inquiries aimed at the delimitation of such human rights risks. ${ }^{88}$

Here is where the potential of the "new" arms trade regulations shines most brightly: while their language may be unclear and prone to loop-holes, or the documents may be criticized for being far from ambitious, they offer a substantially improved avenue for human rights litigation and advocacy at the highest levels by substantially lowering the threshold of State's responsibility over their own arms exports. Thus, the added value of employing a human rights framework to the global arms trade can be seen in the fact that it provides enhanced thresholds of protection and responsibility, particularly suitable for the contexts of non-international armed conflicts, as they facilitate

84 R. Hamann et al. "Business and human rights in South Africa: An analysis of antecedents of human rights due diligence." Journal of Business Ethics 87.2, 2009, 453-473., p. 470.

85 Ibid. supra note.

86 M. Brehm. "The Arms Trade and States' Duty to Ensure Respect for Humanitarian and Human Rights Law." Journal of Conflict and Security Law 12.3, 2007, 359-387., p. 382.

87 According to the User's Guide to Council Common Position 2008/944/CFSP defining common rules governing the control of exports of military technology and equipment, States should, inter alia $a_{s}$ assess the role of the end user within a certain State, whether the equipment has been used before for internal repression, human rights implementation and ratification records of the country of destination and human rights transparency. 
enormously the triggering of the international responsibility of transferring States in every case in which they failed to take reasonable steps to prevent violations committed through or facilitated by their exports.

The AтT and the Common position therefore give rise to the distinct, and new, possibility of engaging human rights due diligence responsibilities of the exporting States. Since these States are now required to assess on a case-by-case basis the human rights risks of their arms transfers, they are in a prime spot to face liability under this framework. This is so precisely because both documents posit a duty to prevent serious human rights violations, and therefore create a positive obligation of due diligence. As a result of this positive obligation, these human rights-based concerns may now constitute a sufficient basis to prohibit certain arms transfers in cases of human rights violations abroad. ${ }^{89}$

\section{8}

\section{Concluding Remarks}

This article sought to explore how human rights concerns have come to crystallize within arms trade agreements. In this paper, it has been shown that they appear in the form of human rights risk assessment models, which appeared as early as in the European Code of Conduct. ${ }^{90}$ As a result of EU normative entrepreneurship, this paradigm has been dominant ever since. ${ }^{91}$ It has meant the need for a case-by-case analysis of the risks on human rights that a given arms transfer may potentially have, and therefore, instead of prohibiting arms exports to States involved in human rights violations, exporting States have to evaluate future risks. Only if these thresholds are met in relation to potential "serious violations" or "internal repression", are the exporting States required to deny an arms transfer. Both documents that lay at the core of this article, namely, the ATT and the Common Position, identify similar principled risk factors, such as membership to human rights treaties and developed accountability policies. However, both instruments also include decidedly vague and unclear notions of "clear risks" and "overriding risks" that state parties are obligated to assess, without providing much substantive interpretive guidance on what precisely constitutes such risk.

Nevertheless, as has been argued, the existence of this preemptive riskassessment mandate does indeed create a new interesting scenario in which States are required to either know or have known the human rights risks

\footnotetext{
89 M. Brehm, 2007 (n 86).

$90 \quad$ N. Cooper, 2006 (n 11).

91 A. Bailes, 2008 (n 15).
} 
associated to a certain arms transfers. As such, it is argued that member states now face due-diligence obligations in this regard. It is further argued that the interplay of the human rights risk management trends within both the ATT and the Common Position set the stage for this form of responsibility playing a prominent role in future efforts to curb international arms trade and enhancing human rights-linked advocacy.

Despite these welcome developments, awareness needs to be raised on the fact that the risk thresholds present in both documents are extremely blurred and unclear, and have to be juxtaposed with competing interests, such as the protection of human rights in a buyer's market. ${ }^{92}$ This has meant varying outcomes in the degree of human rights protection afforded by these documents: for some States, a risk will be sufficient to deny a transfer, while for others the same scenario will not be "clear" enough or "overriding" enough. In the end, it is the State domestic authorities who are in charge of assessing risks. While it is therefore obvious that neither the ATT nor the Common Position are the perfect solution to the human rights risks associated with the international arms trade, it is necessary to argue that they do constitute flexible enough frameworks so that substantial improvements can be made in the future, particularly by substantiating human rights due diligence, and that is a welcome starting point.

With this in mind, a few possible ways forward can be sketched. First, as it has been discussed above, both the ATT and the Common Position need to clarify the scope of their language by developing frameworks or procedures that can establish clear-cut thresholds of acceptable and unacceptable human rights risks. This should be a short-term priority. Secondly, further developing human rights due-diligence as a trigger of State responsibility and acknowledging that States have placed such responsibility upon themselves via the both the ATT and the Common Position are desirable mid-term goals. It appears clear that in achieving these goals, the role of state parties in relation to both the aforementioned documents and the OSCE will be key to providing best-practice tools and interpretation for effective implementation. ${ }^{93}$ While this is no easy task, such advances are fundamental if we intend to curb the impact of arms transfers on human rights in what has become essentially a buyer's market, where dependency on buyers and GDP concerns often override human rights considerations. ${ }^{94}$

\footnotetext{
92 S.T. Hansen and N. Marsh, 2015 (n 30), p. 282.

93 P. Holtom, 2016 (n 34), p. 338.

94 J.R. AI, and S.L. Willardson, 2019 (n 52 ).
} 